\title{
George Kopits
}

\section{Political Economy of Fiscal Reform in Central and Eastern Europe}

The reform of public finances has been at the centre of the post-socialist transition of Central and Eastern Europe since the early 1990s. At various stages of the transition, the reform process encompassed the entire gamut of public finances: the national budget, sub-national finances, extrabudgetary operations, and state-owned financial and non-financial enterprises. For the most part, fiscal reform was a non-linear stop-and-go process - often characterised by backtracking as well - and was uneven across countries. Moreover, unlike most reform experience in the rest of the world, fiscal reform in this region took place against the backdrop of a radical break, as sovereign countries emerged from a colonial past following the collapse of the Soviet Union. An important milestone was reached in 2004-2007, when all ten countries 1 covered in this article became members of the European Union. The purpose of this article is to discuss fiscal reform in Central and Eastern Europe from the perspective of political economy. Following an overview of basic reform trends, the article focuses on the principal drivers and impediments to reform in the region. To conclude, the ingredients of successful reform are examined. The article does not provide an exhaustive inventory of reform measures, nor does it offer a survey of broad political economy issues prior to or during the transition period.2 Country references are intended to serve as stylised illustrations of main points, rather than as a comprehensive documentation of reform episodes.

Journal of Economic Literature (JEL) classifications: H1, H3, P2, P52.

Keywords: political economy; public finance; transition economies.

Through the end of the 1980s, the fiscal system of Central and Eastern European countries was cast in a socialist centrally planned regime. The system was characterised by the subsidised provision of merit goods and services through state-owned enterprises, operating under a soft budget constraint. The subsidies as well as large investment projects (mostly prestige projects) were financed largely with highly opaque and non-parametric levies which, in turn, were determined by price and wage controls. All key policy decisions emanated from the central plan. With the fall of the Iron Curtain, these countries abandoned central

George Kopits Chairman of the Fiscal Council, Republic of Hungary. This paper was presented at the OECD Meeting of Senior Budget Officials, in Bucharest, April 9-10, 2008. The views expressed are those of the author and do not necessarily reflect those of the Fiscal Council.

1 Bulgaria, Czech Republic, Estonia, Hungary, Latvia, Lithuania, Poland, Romania, Slovak Republic and Slovenia.

2 For a discussion of such issues under socialist central planning, see Kornai (1992), and under post-socialist transition, see Roland (2000), Kolodko (2000), and Csaba (2005). 
planning and embarked on an unprecedented market-oriented transition, with a view to eventually joining the European Union. ${ }^{3}$

The initial conditions and the pace of transition differed across countries in various areas, most notably in the reform of public finances. Hungary, Poland and the former Yugoslavia had already launched limited reform initiatives in the previous decades and were best prepared for the transition. By contrast, without any prior reform measures, the former German Democratic Republic moved almost instantaneously from the most rigid central planning to full unification with the Federal Republic of Germany (FRG).

Given more advanced initial conditions, Hungary and Poland took the lead in liberalising prices, wages, interest rates and external trade. Alternative routes to privatisation were chosen, between formal mass privatisation in Czechoslovakia and a pragmatic yet effective case-by-case or sectoral approach - laced with insider trading behaviour - in Hungary, Poland and Slovenia. In addition, in the case of Hungary, enforcement of the strictest bankruptcy legislation helped restore an arm's-length relation between government finances and the enterprise sector. Except for the early introduction of the value-added tax (VAT) and income taxes in Hungary, tax reform and phase-out of price subsidies were much more gradual than anticipated in most countries. However, in the Baltics, the reform process gained momentum on all fronts in the second half of the 1990s, placing this group ahead of the rest. By the end of the 1990s, transition in the fiscal area had reached a critical mass in Central Europe (CE) and the Baltic countries. ${ }^{4}$

Perhaps the slowest area of reform was the social security system, encompassing public pensions, health care, unemployment insurance and social assistance. With strong World Bank prodding, most countries (except the Czech Republic) introduced a governmentmandated private defined-contribution pension scheme, though without adjusting the parameters of the traditional defined-benefit scheme and neglecting the budgetary costs of transition to the new scheme.

The reform of the public administration, including rationalisation of the government work-force, was also relatively slow. The practically unchanged size of government employment in several CE countries can be explained in part by the different depth of the transition in the tradable versus the non-tradable sectors. The tradable sector, fully exposed to foreign competition, bore the brunt of a severe transformational contraction and attendant unemployment. Meanwhile, the non-tradable sector, including the public administration, remained protected and was hardly forced to shed any employees.

Broadly speaking, by the time of EU accession, most countries had completed the market-oriented transition, and the structure of their public finances is now comparable to that in most European economies (see Kopits 2006). Yet important differences prevailed between the Baltics and the CE members concerning government size, fiscal balance and public debt sustainability. Whereas in the Baltics, as well as in the Slovak Republic, general government outlays total less than $40 \%$ of GDP, in the other countries they are close to the EU average of nearly $50 \%$ of GDP. The government wage bill as a ratio to GDP and the share of public employees in total employment in Hungary, Poland and Slovenia are

\footnotetext{
3 See Kopits (1991) for an early assessment of fiscal reform in Central and Eastern Europe. Other contributions on specific issues and countries can be found in Tanzi (1993) and in Kopits (1994a, 1994b, 1994c).

4 See Tanzi and Tsibouris (2000) for an overview of fiscal reform in all transition economies in the 1990s.
} 
high by OECD standards. Overall, the larger CE economies stand out for their structural weaknesses and long-term sustainability problem. ${ }^{5}$

Tax rates are lower and more uniform and spending programmes are more modest in the Baltics than in the larger CE countries. The tax system of the latter, unlike that of the Baltics, is plagued by relatively narrow and distorted tax bases and high marginal rates. Effective tax bases have been eroded by administrative shortcomings and proliferation of tax preferences. In recent years, the Baltics, Romania and the Slovak Republic took a bold step that generated considerable international attention, with the adoption of flat taxes on personal income at a low uniform rate that was extended to the VAT and company income taxation as well.

A number of expenditure-related problems remain, especially in the major $\mathrm{CE}$ countries: excessive public payroll, dysfunctional application of social security programmes, inadequate targeting of social assistance, and overall lack of cost-consciousness in the provision and consumption of public resources - problems that are compounded by considerable programme rigidities. In addition, budget procedures are far less effective than in the Baltics. ${ }^{6}$

In the $\mathrm{CE}$ countries, easy eligibility for disability and early retirement pensions, and for sickness benefits, is seen as a means of soaking up structural unemployment. Among OECD countries, Poland stands out with the highest proportion of the working-age population claiming disability pension benefits, by a wide margin. Family benefits and education are freely available in these countries regardless of household income or wealth. High consumption of pharmaceuticals in CE countries is induced by generous subsidisation; the Czech Republic, Hungary and the Slovak Republic rank among the OECD countries with the highest proportion of pharmaceuticals in total health-care expenditures.

Given insufficient revenue, as well as structural distortions and rigidities in expenditure, the larger CE countries have been experiencing fiscal stress since prior to EU accession, manifest in significant imbalances. This condition has been exacerbated by the first-round fiscal costs of EU accession ${ }^{7}$ - reflecting additional expenditure needs and revenue erosion due to increased scope for tax arbitrage - which are yet to be fully absorbed by the new members. With budget deficits in excess of 3\% of GDP, the three largest new members have been subject to the excessive deficit procedure, pursuant to the EU Stability and Growth Pact. By contrast, in the Baltic countries and in Bulgaria, Romania and Slovenia, general government accounts have been nearly in balance or in surplus.

From early on in the transition, the views of economists have converged as to the guiding principles of fiscal reform in the post-socialist transition. First, fiscal policy should encourage efficient resource allocation in the product, capital and labour markets - albeit with government intervention warranted in the event of market failure. Second, the structure of public finances - notably social security programmes - should be sustainable over time - that is, consistent with the intertemporal budget constraint. Third, fiscal institutions should promote social fairness in accordance with the collective value judgment prevailing in each country, but without prejudice to economic goals. Finally, the conduct of government

${ }^{5}$ See the public debt projections in Deroose, Montanino and Wold (2006).

${ }^{6}$ Applying a numerical scoring, Gleich and von Hagen (2003) found that the CE countries lag significantly behind the Baltics as regards the quality of fiscal institutions, degree of transparency and degree of centralisation.

7 According to estimates in Kopits and Székely (2003), the direct net fiscal effect of accession may surpass 4\% of GDP yearly over the medium term. 
(budget process, procurement practices, tax administration, etc.) should be effective and should follow criteria of good governance (including codes of transparency and conflict of interest) in conformity with internationally agreed standards of good practice.

From broad agreement on these defining principles, it is rather straightforward to derive technical design features of fiscal reform. Hence, the question remains as to why the paths to reform have diverged among countries. For each individual country, a partial answer lies in cultural and historical antecedents and characteristics, which explain preferences with respect to a large versus a small public sector, pay-as-you-go versus a funded public pension system, high versus low tax rates, and so on. However, we can identify political-economy reasons in terms of drivers and impediments to reform, at a more general level, applicable in principle to all these economies. The rest of this article shall examine the role of these positive and negative forces.

\section{Drivers of Reform}

The reform of public finances in Central and Eastern Europe has been driven by widespread regime change, eruption of financial crises and the presence of an external anchor. These three drivers are manifest at varying degrees of intensity in different countries and in different time periods.

\section{Regime Change}

Perhaps the most obvious and powerful reform driver, present to a varying extent in all transition economies, has been the move from socialist central planning to a marketbased economy. As noted, nowhere was the reform effort more intense than in the former German Democratic Republic, where economic life was immediately affected by the wholesale adoption of institutions of the FRG. With some exceptions, further east and south the impact of regime change was slower. For a while in Bulgaria, Romania and the Slovak Republic, the political leadership remained under the control of former officials of the socialist regime.

In essence, regime change involved the introduction of market signals through three overlapping and mutually reinforcing channels. The first consisted of the liberalisation of prices, wages and interest rates. The second subjected enterprises to a hard budget constraint and the risk of bankruptcy, including through the privatisation of state-owned enterprises. And third, the economy was opened to the rest of the world by dismantling barriers to international trade and investment. With an early start, Hungary and Poland were the first countries to allow market forces to prevail through these channels.

On the fiscal front, these changes had major implications for the budget expenditures and revenues and for the structure of the public sector. Price liberalisation and the opening of the economy were accomplished through widespread deregulation, as well as through the elimination of domestic price subsidies, export subsidies and import tariffs. Arm's-length treatment of the enterprise sector entailed reduced budgetary transfers, while application of a transparent and parametric tax structure, along with privatisation (except for the Czechtype mass privatisation), provided a welcome revenue boost.

However, not all transition economies benefited from the opportunity of an initial "honeymoon" effect - often associated with the shift from an authoritarian to a democratic 
regime - afforded by the regime change to implement fiscal reforms. ${ }^{8}$ Some undertook price and external liberalisation at a much slower pace. In other cases, continued state ownership of the banking system led to the accumulation of non-performing and interenterprise credits, imposing a heavy drain on the government budget. Furthermore, even in progressive transition economies, the non-tradable sector was left largely untouched by the regime change and by reform measures. In Hungary, for example, in contrast to massive layoffs in the tradable enterprise sector, the size of the civil service barely changed (at nearly one million employees) for at least a decade (see Kopits 2000).

\section{Financial Crisis}

In many advanced and developing countries alike, debt crises, currency crises and banking crises can provide a major impulse to the reform process. Transition economies were no exception. In 1997, the Czech Republic suffered simultaneously both a currency attack and a bank run in the wake of the Asian crisis. Similar, but more violent, was the debt, banking and foreign exchange crisis, along with a political crisis, experienced a year later by Bulgaria.

The upshot in the Czech Republic was a new round of effective privatisation (as distinct from formal mass privatisation) and bank restructuring, including encouragement of strategic investors from abroad. In Bulgaria, the crises led to the overhaul of social transfers and of the tax structure; in addition, and perhaps more important, the government assumed a commitment to a balanced-budget rule to restore fiscal sustainability.

The threat of a financial crisis, in Poland in 1990 and in Hungary in 1995 and 2006, prompted the authorities to undertake fiscal adjustment-cum-reform programmes to avert potential debt and currency crises. This action included tax increases, investment expenditure cuts, attempts at trimming of social transfers, and eventual adoption of a mandatory funded pension scheme alongside the traditional pay-as-you-go public pension system. In Hungary, recent steps to overhaul the public health-care system and a proposal to establish a rules-based fiscal responsibility framework are intended to reverse a sharp rise in the ratio of public debt to GDP.

\section{External Anchor}

From the early 1990s, a number of transition economies declared their intention, first, to join NATO, OECD and WTO (formerly GATT), then to seek membership in the EU and, more recently, to participate in the euro area. While some of these countries were single-minded in the pursuit of these goals, others have been far less committed. The Baltics anchored all macroeconomic policies (dominated by a hard exchange rate peg), including the public finances, to these objectives. In these countries, political parties and interest groups coalesced behind the goal of joining Western European-based institutions as soon as feasible, presumably motivated by geopolitical, historical and cultural reasons in addition to the obvious economic ones.

8 Such a honeymoon effect endows leaders with enlarged powers to implement reforms, as observed by Haggard and Kaufman (1989) in newly democratic regimes in Asia and Latin America in the 1980s. 
In the fiscal area, this effort translated into a set of reforms that encompassed state-of-theart budgetary procedures, a sustainable social security system and an efficient tax structure. In addition, economic fundamentals were aligned to meet the Maastricht requirements for adopting the euro at an early stage in the EU membership - in stark contrast with the fiscal performance of the CE countries. ${ }^{9}$ Since independence, the Baltics balanced their public accounts while maintaining a textbook-like countercyclical stance. Estonia stands out in this respect: successive governments have adhered to an implicit balanced-budget rule, though with recourse to a macroeconomic stabilisation fund. During upswings in economic activity, surpluses are earmarked for the fund; during downswings, deficits are financed by drawing down reserves in the fund. Thus, in 1998/99, the Baltics managed to dampen the adverse impact of the Russian financial crisis by running large fiscal deficits, followed by significant surpluses in subsequent years.

More recently, with a view to complying with the Maastricht fiscal criteria, the Slovak Republic adopted an ambitious reform-cum-adjustment programme. Against a background of missed opportunities and virtual stagnation, in 2002-06 the centre-right government trimmed welfare transfers, reformed the pension programme, and introduced a flat tax that has become a model for other countries. Interestingly, the successor centre-left government preserved the structural reforms and fiscal discipline, so as to prepare for quick adoption of the euro.

Slovenia can also be seen as having anchored fiscal performance to adoption of the euro, which materialised in January 2007. Indeed, in Central Europe, Slovenia was the only member country of the EU that was exempt from the excessive deficit procedure. However, Slovenia's approach, in both monetary and fiscal policies, has been far more pragmatic and less reliant on reform than the Baltic members or the Slovak Republic. With full participation in the euro area, it is an open question whether the Stability and Growth Pact will provide sufficient incentive to Slovenia for undertaking pending reform measures.

\section{Obstacles to Reform}

Slow progress in fiscal reform, including stop-and-go measures, can be attributed primarily to political-economy factors. In particular, major barriers to reforming social security programmes, subsidy schemes and taxation are: a widespread dependency syndrome, a common-pool problem, a political zero-sum game, and widespread aversion to change. Although these impediments can be found in all post-socialist economies, they are more acute in some countries than in others.

\section{Dependency Syndrome}

A major impediment to fiscal reform stems from the dependency culture inherited from the former socialist regime. The party-state encouraged households to feel dependent on the state - mainly through the state-owned enterprises that employed them - blunting the desire for freedom, personal initiative and responsibility. The dependency syndrome and the associated yearning for security that prevail particularly in the aged strata of the population can be viewed as an explanation for ongoing resistance to fiscal reform in the

${ }^{9}$ For an analysis of the underlying reasons, including the political-economy ones, see Berger, Kopits and Székely (2007). 
region. In effect, the dependency culture is analogous to the attachment to droits acquis entrenched in the welfare-state tradition in much of Western Europe.

In an exploitation of the dependency syndrome, politicians of various stripes tend to cater to interest groups by promising and delivering enhanced social benefits, besides protection of existing benefits. Such populist (or clientelist) competition has been practiced not only by traditional leftist or left-leaning parties, but also by right-wing parties - in some instances, alloyed with patriotic slogans. Although the dependency culture is stronger as we look further east, it is also widespread in Central Europe.

\section{Common-pool Problem}

An additional political-economy impediment - namely, the common-pool problem (also known as commons problem) - is rooted in interest-group dynamics underlying the political process. Simply put, major interest groups (teachers' unions, health-care employees, farmers, multinational firms, etc.) that benefit from the status quo are well represented within the government. By mobilising public opinion, they can effectively block any steps that would serve to dismantle existing privileges, in utter disregard of the budget constraint faced by the government. ${ }^{10}$ These groups are usually most influential within a coalition government or a government that commands a slim majority and/or suffers a significant erosion in popularity.

These conditions are found more often in the larger CE countries. By contrast, they tend to be less pronounced or absent in the Baltics where macroeconomic policies are subject to an external anchor, and in Bulgaria following a severe financial crisis. In these countries, as the political elite and society are sensitised to the aggregate budget constraint, interest groups subordinate their rent-seeking activity to the macroeconomic stability goal and give way to key reform measures.

\section{Zero-sum Game}

Although less prevalent than the other impediments, fiscal reform can be derailed or brought to a halt in a highly polarised political environment where the government and the opposition are in virtual deadlock. In such a situation, each side believes that any reform measure that may politically benefit the other side can only be inimical to its own interests. Clearly, such a non-cooperative game can confer short-term advantage to one political party, but over time at a high cost in terms of forgone benefits for all. In fact, a zero-sum game rejects outcomes that are proven to lead to a win-win situation over the medium to long term.

Although political confrontation is not unknown in some Mediterranean countries, it can be far more intense in post-socialist countries. Regrettably, at present this situation seems to prevail, for example, in Hungary over a wide range of pending reform tasks in the areas of public pensions, health care, education finance, local governments and taxation. A proposed fiscal responsibility framework (requiring legislative enactment by a two-thirds majority) is the latest victim of political deadlock.

10 This attitude was immortalised in the definition of tax reform by the late United States Senator Russell Long: "Don't tax you, don't tax me, tax the fellow behind the tree." 


\section{Resistance to Change}

An almost universal impediment to reform is the inherent resistance to change that is particularly strong in ageing societies, characterised by strong risk aversion. Fear of change - closely related to the dependency syndrome - can be dissolved by a "tipping point" resulting from the dominance of the enumerated reform drivers. ${ }^{11}$ Resistance to change, especially in the mid-age to old-age population, may explain in part the compromise reached of preserving the meagre traditional defined-benefit pension system for older retirees while adopting the new defined-contribution scheme for new entrants in the labour force.

Apart from the fear of various interest groups in losing privileges inherited from the socialist regime, resistance to reform is rationalised and defended by a highly educated intellectual elite, without necessarily any party affiliation or rent seeking. This elite, in some cases appealing to social or national consciousness - ready to charge, for example, against multinational firms - is both eloquent and respected in these countries.

\section{The Ingredients of Successful Reform}

Apart from awareness as to the major drivers and impediments to fiscal reform that are present in various forms or intensity across post-socialist countries, a practical question emerges: how to catalyse reform? Or, stated differently: what are the key ingredients of a successful reform effort? On the basis of worldwide experience with fiscal reform, confirmed for the most part in post-socialist Central and Eastern Europe, three indispensable ingredients can be listed: design, consensus and communication. On the whole, these features characterise fiscal reform in the Baltics more than in the rest of the region.

First, fiscal reform must be technically well designed in terms of internal consistency, comprehensiveness and sequencing. This precludes a piecemeal or stop-and-go approach that can create confusion and lead to a protracted process, and ultimately may undermine support for the reform programme because of reform fatigue. In sum, a coherent strategy has a far better chance of success than a set of poorly co-ordinated measures.

Second, it is essential that the government take every opportunity to build consensus around the set of proposed reform measures. In many respects, this is not merely a technical matter, but rather a culture-specific exercise. It entails bringing together diverse groups in civil society as participants in such a way that all should feel a stake in the outcome, yet be ready to accept some sacrifice for the common good. ${ }^{12} \mathrm{~A}$ sense of fairness in the measures is part of this approach. Contractual obligations (even implicit ones) should be respected through minimum grandfathering of acquired rights. Unnecessary confrontation should be avoided at all cost.

And third, reform proposals, however obvious they might be for experts in the field, should be communicated in a sufficiently clear and credible manner to the population at large. ${ }^{13}$ In particular, every effort should be made to reach out to those who are affected

11 The bestseller by Gladwell (2000) explores various determinants of change.

12 See, for example, the approach suggested by Aaron (1973) as regards welfare reform in the United States.

13 The adoption of Chile's defined-contribution public pension scheme would not have been possible without a systematic communication campaign by the minister of labour. For a discussion, see Pinera (1994). 
directly by the reform measures. ${ }^{14}$ Moreover, effective communication requires not only a credible message, but also credible spokesmen, including widely respected senior government officials, to deliver the message. ${ }^{15}$

\section{Summary and Conclusion}

Overhaul of public finances during the post-socialist market-oriented transition has been a non-linear and uneven process across Central and Eastern Europe. At a technical level, there is broad agreement on the guiding principles of fiscal reform, namely on the need to promote allocative efficiency, sustainability, fairness, effectiveness and good governance. From these criteria, we can derive widely acceptable design features.

However, the composition and pace of fiscal reform ultimately depend on the strength of political-economy drivers relative to obstacles to reform, in a given place and at a given time. On one hand, three major drivers can be identified that catalyse fiscal reform: regime change from socialist central planning to a market economy; financial crises that hit (or are likely to hit) some countries; and the external anchor provided by participation in various international institutions, but above all by EU accession and by adoption of the euro. On the other hand, there are four major inter-related impediments to reform: the dependency syndrome, inherited from the socialist regime; the common-pool problem, whereby key interest groups seek to preserve their privileges regardless of the fiscal consequences; a zerosum game among political parties; and fear of change, especially in ageing populations.

If the drivers outweigh the impediments, reforms have a good chance of being implemented. But ultimately fiscal reforms are more likely to succeed (and less likely to be reversed) if they are technically well designed, based on broad consensus, and communicated effectively and credibly.

\section{References}

Aaron, H.J. (1973): Why is Welfare so Hard to Reform?, Chapter 6, Brookings Institution, Washington DC.

Berger, H., G. Kopits and I. Székely (2007): Fiscal Indulgence in Central Europe: Loss of the External Anchor? Scottish Journal of Political Economy, Vol. 54, February, pp. 116-135.

Csaba, L. (2005): The New Political Economy of Emerging Europe. Akadémiai Kiadó, Budapest.

Deroose, S., A. Montanino and I. S. Wold (2006): The EU Approach to Fiscal Sustainability. In: Fiscal Policy and the Road to the Euro. National Bank of Poland, Warsaw, pp. 87-120.

Gladwell, M. (2000): The Tipping Point: How Little Things Can Make a Big Difference. Back Bay Books, New York, United States.

Gleich, H. and J. von Hagen (2003): The Evolution of Budget Institutions: Evidence from Central and Eastern European Countries. ZEI (Center for European Integration Studies), University of Bonn, Bonn, Germany.

Haggard, S. and R. Kaufman (1989): Economic Adjustment in New Democracies. Chapter 2 in: J. Nelson (ed.): Fragile Coalitions: The Politics of Economic Adjustment. Overseas Development Council, Washington DC.

${ }^{14}$ A recent episode that seems to violate the so-called "red face test" was the unannounced reduction in social benefits in the Slovak Republic, which contributed to riots in some of the more backward parts of the country.

${ }^{15}$ For example, a senior government official who is suspected of tax evasion is not competent to campaign for tax reform; similarly, a high official who is known for having amassed a fortune with privatised assets on the basis of insider information is not a credible spokesman for introducing transparency in government procurement practices. 
Kolodko, G. (2000): From Shock to Therapy: The Political Economy of Postsocialist Transformation. Oxford University Press, Oxford, United Kingdom.

Kopits, G. (1991): Fiscal Reform in European Economies in Transition. In: P. Marer and S. Zecchini (eds.): The Transition to a Market Economy: Volume 2 - Special Studies, OECD Publishing, Paris, pp. 359388.

Kopits, G. (1994a): Midway in the Transition. Acta Oeconomica, Vol. 46(3-4), pp. 267-292.

Kopits, G. (1994b): Monetary and Fiscal Management during the Transformation. In: H.J. Blommestein and B. Steunenberg (eds.): Government and Markets: Establishing a Democratic Order and a Market Economy in Former Socialist Countries, Kluwer, Dordrecht, Netherlands, pp. 231-246.

Kopits, G. (1994c): Lessons in Fiscal Consolidation. In: H. Siebert (ed.): Overcoming the Transformation Crisis: Lessons for the Successor States of the Soviet Union. Institute of World Economics, Kiel, Germany, pp. 257-277.

Kopits, G. (2000): Comment on 'Macroeconomic Policies and Achievements in Transition Economies, 198999’ by S. Gomulka. In: Economic Survey of Europe. UNECE, Geneva, Switzerland, pp. 86-88.

Kopits, G. (2006): Fiscal Reform in the New Member States: Prospects and Retrospect. In: Fiscal Policy and the Road to the Euro, National Bank of Poland, Warsaw, pp. 191-203.

Kopits, G., and I. Székely (2003): Fiscal Policy Challenges of EU Accession for the Baltics and Central Europe. In: G. Tumpel-Gugerell and P. Mooslechner (eds.): Structural Challenges for Europe. Edward Elgar, Cheltenham, United Kingdom, pp. 277-297.

Kornai, J. (1992): The Socialist System: The Political Economy of Communism. Clarendon Press, Oxford, United Kingdom.

Pinera, J. (1994): Chile. In: J. Williamson (ed.): The Political Economy of Policy Reform. Institute for International Economics, Washington DC, pp. 225-231.

Roland, G. (2000): Transition and Economics: Politics, Markets, and Firms. MIT Press, Cambridge, Massachusetts, United States.

Tanzi, V. (ed.) (1993): Transition to Market: Studies in Fiscal Reform. International Monetary Fund, Washington DC.

Tanzi, V., and G. Tsibouris (2000): Fiscal Reform Over Ten Years of Transition. IMF Working Paper WP/00/113, June, International Monetary Fund, Washington DC. 